\title{
A Study on the Relationship between Perceived Organizational Support and Job Satisfaction with Organizational Commitment in Mellat Bank, Khoramabad, Iran
}

\section{Sasan Mohammadpanah}

\author{
Student of Faculty of Public Administration Post- graduation Department, Islamic Azad University, Borujerd Branch, Iran \\ Arasteh St., Enghelab, Khorramabad, Lorestan, Iran, Postal Code: 6816844585; Email:S.panah50@gmail.com;address:5th \\ Corresponding Author: Sasan Mohammadpanah
}

\section{Doi:10.5901/mjss.2016.v7n3s1p496}

\begin{abstract}
The purpose of the present study is to investigate the relationship between perceived organizational support and job satisfaction with organizational commitment of Khoramabad-branch Mellat bank staff. This research is a descriptive survey and three kinds of questionnaires has been used in it (cognitive supporting questionnaire of Eisenberger, Huntington , Hutchison and Sowa 1986, job satisfaction questionnaire of Paul Spector 1994 , and Allen and Meyer organizational commitment questionnaire 1997 ). The intended society includes Khoramabad bank staff that have been involved 122 persons which 93 of them were chosen as sample according to Morgan's table and systematic sampling. The research findings show that: - There is a direct relationship between organizational supporting realization and organizational commitment. - There is a direct relationship between occupational satisfaction and organizational commitment.
\end{abstract}

Keywords: Perceived Organizational Support, Job Satisfaction, Organizational Commitment.

\section{Introduction}

Many researchers believe that since early 1950s in which the organizational commitment was figured in the field of organizational behavior; this issue has been changed to one of the researchers' favorite subjects. Because they believe that the right management of organizational commitment can cause useful results such as function improvement, relocation decreasing, the decreasing of the staff absence and organizational effectiveness (Aarabi , 2011). One of the factors that can play the main role in the accomplishment of organization goals is organizational commitment. Simply, the definition of organizational commitment is faithfulness to the values and organization goals, loyalty to the organization, moral commitment, strong tendency and the need to stay in the organization; according to Allen and Meyer point of views, 3 factors are assigned to it: emotional commitment, normative commitment and permanent commitment. Researchers have shown that interested and devoted staff to the organization have more function and benefit; they have more motivation; indeed they show more agreement while they accompany the organization with its shifts more , therefore the organization can fulfill its favorite goals by making use of the knowledge of the amount of their staff organizational commitment and by shifting the effective factors on it. The staff-perceived organizational support and their job satisfaction are considered as the most important effective factors on organizational commitment. Organizational support is defined as a group of obvious feeling and belief to the idea that organization pays values to cooperating and supporting its staff, and is worried about their happiness and their future.

Job satisfaction is a collection of feeling and belief that people are involved in about their job, in other words job features and conditions, the conditions in which the job has been done are admired, and reward has been awarded for it. According to these issues, the researcher has survived the relationship between perceived organizational support and job satisfaction with organizational commitment among Khoramabad Mellat bank staff.

\subsection{Study Background}

This study has been done in the field of organizational behavior and human resources from September to March, 2012 in Mellat bank, Khoramabad-branch. 


\subsection{Statement of Problem}

Due to its important for the organization, organizational commitment always has been the subject of studies. According to flouting working population in present world, organizations try to understand how they can keep their staff and attract their loyalties, and are looking for the ways to increase the staff commitment to the organization. Despite several researches on the organizational commitment regarding different reasons such as the difficulty in description and measuring organizational commitment, different variants in micro and macro levels, and its objectivity and subjectivity, cultural differences and variety of theories in organizational commitment changes and its identification, the result of these studies cannot be distributed with enough certitude. Different studies in different organizations show that in order to create more efficiency and strong tendency to keep up with jobs among the staff, they should be supported by organization; indeed they should enjoy job satisfaction and attachment to the organization, also they should feel more responsibility to do their duties which they cause deep realization of their job and self-devotion among them. According to the mentioned issues, the main problem of research is that how much the perceived organization support and job satisfaction as the independent factors can forecast the amount of organizational commitment as a dependent factor among Khoramabad bank staff.

\subsection{Research Goals}

The main goal of this study is considering the relationship between perceived organizational support and organizational commitment among Khoramabad Mellat bank staff and the secondary goals of this research are:

1) Determining the amount of job satisfaction among Khoramabad Mellat bank staff.

2) Determining the amount of Khoramabad Mellat bank staff's perceived organizational support.

3) Determining the amount of Khoramabad Mellat bank staff's organizational commitment.

4) A survey on the relationship between job satisfaction and organizational commitment of Khoramabad Mellat bank staff.

5) A survey on the relationship between perceived organizational support and organizational commitment of Khoramabad Mellat bank staff.

6) A survey on the relationship between perceived organizational support and job satisfaction of Khoramabad Mellat bank staff.

\subsection{Significance of Study}

By entering to the millennium III, new research topics were developed in organizational surveys. After a short time, they have found an important position in literature and among organizational theories such as organizational support, organizational trust and organizational commitment. Using better human resources as a useful apparatus in organizational efficiency improvement is a new aspect in organizational behavior management. Therefore, the theorists have attended to human resources, not only in its traditional roles, but also in its influence on other efficiency key factors (Rezaeian, 2001). Peter Drucker, the father of modern management, believes that the biggest proportional advantage will be organizations and countries' human force in the future competitive world. Today the minds' added value is more valuable than other resources.

The most important element of any organization is human force. Different from other factors of production and organizations' inside resources, human is the only creature who is determiner and performer; therefore it is considered as a gravity center for organizations' success (Amirkabiri, 2010). If it is accepted that the human investment is the biggest and the most valuable property of any organization, it should be accepted that anything that's more expensive and more valuable needs better keeping and protecting.

Of the most important items which should be attended in keeping the staff in any organization are job satisfaction and organizational support of staff that can cause an increase in staff organizational commitment.

Managers' supporting behaviors and organizational environment can cause the perceived organizational support provided by the staff. The concept of organizational support is better identified when organization valorizes for its member cooperation and worries about their future. Regarding the importance of the subject, it must be mentioned that the staff feeling the special atmosphere of happiness and satisfaction play their role in the organization as an active member. The staff who receive more organizational support feel that they should work based on suitable attitude and behavior in organization such that their function will be according to the benefit of their organization (Zaki , 2006).

There are a lot of reasons that why an organization should increase its members' organizational commitment. First 
of all, organizational commitment is a new concept and is generally different from dependency and job satisfaction; for example the organization staff may do a work which they are interested to while they may not be satisfied with the organization in which they are working. In this case they search similar jobs in other similar places. Second, there is a positive relationship between organizational commitment and special consequences such as job satisfaction and an increase in job performances while there is a negative relationship with the tendency to leave the job.

In order to implement article 44 of the Constitution which its general policies implementation purpose is to increase efficiency, productivity and economic competitiveness of the country in order to achieve economic growth and expansion of economic welfare of the people. Since one of the ways to increase the efficiency and productivity of the banks is the changing of state management to private one, Mellat bank was one of the state bank that got out to the private banks in 2008. According to the increasing number of emerging banks and financial and credit institutes, intense competition arose for obtaining the stake of the markets among the banks. Today in the banking market, with the advent of various banks and financial institutions and increasing the awareness and expectation of customers, traditional beliefs and functions are not useful anymore, and the factors which brought about success in the past, don't have efficiency anymore.

The continuous changes in the field of competitors, services, products, customers and in fact changes in business environment require intelligent organizations which are equipped with intelligent human capital to make themselves ready regarding the changes to be present at a serious competition. In the current situation, Mellat bank needs a special mutation and a supremacy in various sections to make a distinction among other banks which is accessible only by the staff who have organizational attachment, commitment and loyalty. In this regard Mellat bank tries to provide the benefit of main bank owners and stockholders besides doing assigned social responsibility. Regarding human resources of this bank who are actually some of its stockholders are considered as the most known valuable assets and sources. It is necessary to measure the amount of staff organizational commitment and the effective factors on it to maintain it more than before and to provide a basis for growth of organizational commitment. In this research, we try to study the relationship between perceived organizational support and the staff job satisfaction with the organizational commitment.

\subsection{Literature Review}

Today, organizations have understood the importance of human resources as the most important source of competitive advantage. Present organizations compete for attracting and keeping the human resources by presenting welfare programs and by their amount of attentions to the staff (Taleghani , Divandari \& Shirmohammadi , 2009).

In respond to the wave of competition over human resources, organizations invest on the implementation and improvement of welfare programs and supporting the staff; and are trying to provide the appropriate facilities and amenities for their staff as much as possible. In last 2 decades speaking about such issues and debating about welfare programs and supporting staff were unusual; but today there are a lot of organizations which perform these programs. These organizations have understood that they can get the most profit out of investing on the welfare improvement and staff support because the staff who feel supported get satisfied; they have less absence, and don't leave the organization simply; these factors improve the organizations' function and lead them achieve their goals. The study over job satisfaction is important because of two aspects:

1) From human aspect: it is essential to respect the staff and behave them fairly.

2) Behavior aspect: attention to job satisfaction can guide the staff behavior in such a way which effects on their function and organizational duties, and can cause their positive or negative behavior. Generally, the effective factors on staff job satisfaction are divided to two main parts such as environmental, occupational, and human factors. When people's occupational and routine life set together, they will be happier and more satisfied (Rezaeian 2001). One effective factor in organizations and companies is the amount of organizational commitment of organization members; organizational commitment has clear effect on efficiency and productivity. In recent years, organizational commitment has been the main part of organizational research.

\subsubsection{Perceived Organizational Support}

The concept of perceived organizational support was first developed in 2007; it entered from psychology to management literature and it was warmly received by organizational researches and administrative managers.

Perceived organizational support refers to the staff belief that how much the organization considers the value of their cooperation and emphasizes on their welfare. Today, after more than two decades from researches in this field, it becomes more and more important; and the researches in this field are expanding very fast. Intercultural researches and studies over organizational support concept are done in the cultural bed of any countries except western countries. On 
the other hand, nowadays in Iran, the process of performing article 44 of constitution and a privatization of state organizations modulates human resources to the competitive ones. During implementation of article 44 of constitution, competitive feature of organizations to engage and maintain human resources increases the importance of study over organizational support and commitment among staff. For the first time, Eisenberger and his teammates introduced the concept of perceived organizational support in Journal of applied psychology in 2008. According to Eisenberger and his teammates definition, the staff feel being supported from organization when the organization considers the value for their cooperation and emphasizes their welfare. Theory of social transmission is considered as fundamental theory of organizational support. According to this theory, in social relationship when someone does a favor to another person, the other person feels it necessary to recompense his favor. The bigger this favor and help is, the more tendency to be recompensed. Researchers believe that there is also such a social exchange between staff and employers, because the organization is a source to meet the needs of staff; therefore the exchanging relationship between staff and employers seems to be true. The organizational support theory claims that staff generate a general view point of the amount of organization support toward themselves, so they pay attention to the goals and to their fulfillment as much as they receive support. In other words, when the organization attends to staff welfare, they recompense this attention by more commitment and better function.

Social transmission theorists believe that the value of transmitting relationship increases when it is done arbitrarily. When the staff feel that the organization attends to their welfare, neither for legal commitment nor union pressure, they give a better response to it ; and do better to fulfill . Furthermore the organization is considered as the satisfaction source of some staff's social needs such as identification, attachment, and self respect. For keeping these requirements' source, the staff help the organization to fulfill its goal according to transmission norm. (Taleghani, Divandazi \& Shirmohammadi, 2009). When the staff perceive that the organization is worried about their happiness and presenting assistance to them (organizational support), staff think of the organization as their identification source and feel more loyalty and devotion (organizational commitment)toward it. Base on organizational support theory three general factors bring about appropriate behavior in organization: justice and equality, supervisor's support and organizational rewards and occupational fields. Organization is the origin of mentioned factors, and finally it will cause an increase in organizational support. Besides, population factors can be added to these factors. Justice is equality in resources distribution among the staff which is called procedural justice. Applying justice as a determining source for resource distribution has a significant effect on perceived organizational support.

The supervisor support is regarded because supervisor's behavior and action is regarded as the symbol of organization. Supervisor's appropriate or inappropriate behavior has a considerable effect on organizational support. If the staff receive the supervisor's support, the organization support will increase. The fulfilling of human resources (organizational rewards and occupational fields) has a special importance in staff's positive reaction (perceived organizational support). Determining suitable opportunities for offering the rewards causes staff's positive evaluation toward perceived organizational support. There is strong relationship between organization's tendency in displaying the significance of occupational future and perceived organizational support. Besides occupational safety, the education and dependence factor in job (positively)effect on organizational supporting. Increase in staff education and their freedom in doing their role and job cause organizational support promotion.

\subsubsection{Perceived Organizational Support Preconditions}

The final group of perceived organizational support preconditions is the staff's characteristics that is divided in to two general parts.

A. personality: includes self awareness, positive and negative stimulant.

B. population characteristics: such as age, gender, education and work experiences.

\subsubsection{The perceived organizational support consequences}

1) When the staff feel the organization support, their loyalty to the organization increases.

One of the useful and effective ways for increasing organizational commitment is increase in the attention to perceived organizational support.

2) Some of the organizational support effects related to job environment are similar to job satisfaction. Job satisfaction is identified as staff's attitudes and general positive reactions to the job; when the staff feel that the organization supports them, their job satisfaction and happiness are increased. Organizational support causes an increase in staff's positive attitude to their job. 
3) In addition, organizational support affects on the increase in occupational commitment and involvement; that means involvement and interest relate to the job. The more support the staff feel, the amount of their commitment to their job will increase.

4) Increase in perceived organizational support toward staff causes function growth and the staff tendency to stay in the organization; on the other hand it causes decrease in occupational pressure and aggressive behavior (such as willing to leave the job or leaving the job). When the staff see more perceived organizational support, it affects on their functions; the feeling of organizational support causes decrease in the occupational pressures, and it decreases the tendency to leave the job. (Zaki , 2005)

\subsubsection{Its History}

The perceived organizational support idea was formally first developed in organizational literature by Eisenberger and colleagues in 1986; after that the theorists focused on the analysis of the organizational support formation; in addition they studied on the effects and consequences of organizational support on personal and organizational field.

Organizational support is a kind of help or support that the staff need to accomplish the job. On the staff view point, some auxiliary factors include: enough budget, suitable equipment and facilities of doing the job, the availability of high quality products and enough supply of human resources. In studies related to organization development, perceived organizational support is considered as organizational commitment prerequisite. Perceived organizational support can affect on staff's manner and their relationship directly or indirectly. If there isn't enough staff support from the organization, the problem will appear; therefore the manager should check the problems carefully so that if the problem is about the financial shortage, human resources, equipment or facilities, to observe if he can supply the necessary sources reasonably by cost evaluating or not. He should review the goals and should avoid of blaming the staff regarding a position that is out of their control (Rezaeian , 1995)

\subsubsection{Job Satisfaction}

Job satisfaction is identified as the amount of feelings and positive attitudes that people are engaged with in their job. When a person says that he enjoys a high educational satisfaction, it means that he really likes his job, has good feeling about it, and knows his job valuable.

The researches results show that staff with more job satisfaction enjoy good physical situation and mental ability. Job satisfaction is the result of staff's comprehension; that means job supplies the valuable opportunity for the staff. The first step for obtaining a valuable, satisfactory and successful job seems to be finding an occupational opportunity that has been in accordance with staff's personal interests (Dubrin, 2008). Job satisfaction is a positive feeling that is a result of occupational evaluations or the person's experiments. This positive feeling helps to people's physical and mental health.

Staff job satisfaction is divided in to two types of satisfactions: external satisfaction and the internal one. In external satisfaction, staff show their satisfaction of several factors such as payment, promotion, supervisor admiration and their behavior toward their colleagues (according to their duties), and in internal satisfaction, the staff show their satisfaction such as values, responsibilities, social class, position, dependency and self esteem originated from duty and works.

Person's evaluation about his work and showing satisfaction and dissatisfaction of that job is a general result from a collection of different factors which makes his job (Robbins, 1995).

Two usual methods for job satisfaction measurement:

A. General comparison: A question is asked from staff, for example according to all occupational aspects that you have, how much are you satisfied with your job?

B. Elaborative method: In this method, all the occupation aspects have been determined, and the persons' feelings about them are asked. Some of these factor s are: occupational identity, leadership, income, promotion opportunity and the relationships with the colleagues. According to one special standard, these factors have been given a score; then for determining the job satisfaction score, we add all of them with each other.

\subsubsection{Organizational Commitment}

Sheldon (1971) identified organizational commitment as an attitude or orientation toward the organization which relate the person's identity to the organization. Kanter (1973) determined it as a person's tendency to provide the social system with 
his energy and loyalty.

Based on Moody and his colleagues, organizational commitment is determination of a person's general relative degree to a special organization and his involvement and cooperation with that organization (Aarabi, 2011). From Allen and Meyer point of view, organizational commitment is a kind of attitude which shows the amount of staff interest, attachment and loyalty to the organization and their tendency for staying in organization. The origin of this attitude can be because of person's tendency, obligation or need, and it has three aspects:

emotional Commitment: Demonstrates the person's attachment, dependency and identity attachment with organization's values and goals.

Normative Commitment: Demonstrates the responsibility and moral obligation for staying in organization.

Continued Commitment: Demonstrates the person's recognition and comprehension from the organization leaving costs (necessity to stay in organization).

\section{Materials and Methods}

\subsection{The approaches of the Staff Commitment Fortification :}

In order to increase the staff commitment, organizations have made lots of attempts, and presented lots of solutions; some of these solutions are as follows:

1) Ideology and common ideal creating :(In fact ideal offers a future perspective which we want to make it, and ideology specifies the staff behavior's frames) (Management Development Monthly, October , 1998)

2) Value- based Employment: In most organizations, the organization socializing process prior to employment starts by employing based on the organizational values, so the individuals who are suitable and match with the organizational values are employed.

3) Educational and value orientation: It is identified as leading the staff toward the values and the organizational culture which enjoys a great importance.

4) Electing a suitable leader: An effective leadership inspires and motivates the staff, the interested and eager staff are encouraged along organization's common aims. Competition and willing to show suitable reaction against environmental factors require the staff to indicate more commitment to the organization. Increasing and creating staff commitment (it means the staff goals and organization goals are along each other in a way that the people try to do their duties in an organization in which they work as if it is their personal organization) need different activities meanwhile human resource management plays the main role.

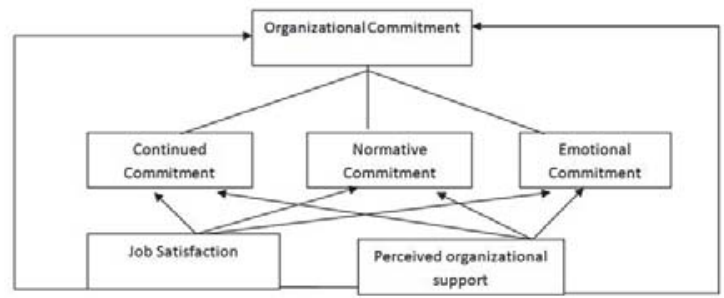

Figure 1. Research Conceptual Model

\subsection{Research Methodology}

Research methodology is the study of a collection of doctrines, rules and investigations which guide us toward the scientific knowledge.

Table 1. Methodology

\begin{tabular}{|c|c|c|c|c|c|c|}
\hline$\frac{\text { Research }}{\text { Purpose }}$ & $\begin{array}{l}\text { Method } \\
\text { Data Model }\end{array}$ & $\begin{array}{l}\text { Data Analysis } \\
\text { Method }\end{array}$ & Statistical Population & $\begin{array}{l}\text { Statistical } \\
\text { Sample }\end{array}$ & $\begin{array}{l}\text { Sampling } \\
\text { Method }\end{array}$ & $\begin{array}{l}\text { Data Gathering } \\
\text { Tools }\end{array}$ \\
\hline Applicat & Qualitative & Correlation & $\begin{array}{l}\text { Khoramabad Mellat Bank } \\
\text { Staff (122 individuals) }\end{array}$ & $\begin{array}{l}99 \\
\text { individuals }\end{array}$ & $\begin{array}{l}\text { Systematic } \\
\text { Sampling }\end{array}$ & Questionnaire \\
\hline
\end{tabular}


Table 2. Research Theories and Results from Pearson's Correlation's Test

\begin{tabular}{|c|c|c|c|}
\hline Theories & Level of Significance & Pearson Value & Result \\
\hline $\begin{array}{l}\text { The first main theory: There is a meaningful relationship between } \\
\text { organizational satisfaction and organizational commitment. }\end{array}$ & $\% 000$ & $\% 578$ & Relationship \\
\hline $\begin{array}{l}\text { The second main theory: There is a meaningful relationship between } \\
\text { perceived organizational support and organizational commitment. }\end{array}$ & $\% 000$ & $\% 456$ & Relationship \\
\hline $\begin{array}{l}\text { The first secondary theory : There is a meaningful relationship between } \\
\text { organizational satisfaction and emotional commitment. }\end{array}$ & $\% 000$ & $\% 624$ & Relationship \\
\hline $\begin{array}{l}\text { The second secondary theory: There is a meaningful relationship } \\
\text { between organizational satisfaction and normative commitment. }\end{array}$ & $\% 006$ & $\% 283$ & Relationship \\
\hline $\begin{array}{l}\text { The third secondary theory: There is a meaningful relationship between } \\
\text { organizational satisfaction and continued commitment. }\end{array}$ & $\% 16$ & $\% 248$ & Relationship \\
\hline $\begin{array}{l}\text { The fourth secondary theory: There is a meaningful relationship between } \\
\text { perceived organizational support and emotional commitment. }\end{array}$ & $\% 000$ & $\% 613$ & Relationship \\
\hline $\begin{array}{l}\text { The fifth secondary theory: There is a meaningful relationship between } \\
\text { perceived organizational support and normative commitment. }\end{array}$ & $\% 114$ & $\% 165$ & Lack of Relationship \\
\hline $\begin{array}{l}\text { The sixth secondary theory: There is a meaningful relationship between } \\
\text { perceived organizational support and continued commitment. }\end{array}$ & $\% 529$ & $\% 66$ & Lack of Relationship \\
\hline $\begin{array}{l}\text { The seventh secondary theory: There is a meaningful relationship } \\
\text { between organizational satisfaction and perceived organizational support }\end{array}$ & $\% 000$ & $\% 642$ & Relationship \\
\hline
\end{tabular}

\section{Results and Discussion}

Regarding privatization of Mellat bank and the necessity to supply investors and stockholders benefits also along achieving the bank's perspective to become the pioneer bank, special attention to human resources has been felt more than before.

In this study, it has been tried to evaluate the amount of perceived organizational support, job satisfaction and Mellat bank organizational commitment also to investigate on their relationships. The study final findings are:

-The results have shown that there is a positive and meaningful relationship between job satisfaction and organizational commitment; in other words, some factors such as salary and benefit, staff job stability, suitable and fair award distribution, available opportunities and promoting job possibility among staff bring about organizational commitment and cause them to know themselves as active members in organization; besides showing moral commitment to stay with the organization, they feel attached to it, and their loyalty to organization increases. In this study, it was clarified that there is a correlation coefficient between job satisfaction and organizational commitment(0.578) which its level of significance was 0.01 ; in other words, it can be expected that by increasing job satisfaction, organizational commitment increases simultaneously.

This finding was compatible with other researches findings (Madani, 2000; Talebpour, 2001; Beenet \& Durkin, 2000; Jennifer parker Ayers, 2010)and confirms their findings. In their researches, they understood that job satisfaction is one of the important and effective factors on organizational commitment and there is positive and strong correlation with it.

-The research result show that there is a positive and meaningful relationship between job satisfaction and three factors of organizational commitment (emotional, normative and continued). The calculated correlation coefficient say that the strongest relationship is the relationship between job satisfaction and emotional commitment (\%62.4)and one weak relationship is the relationship between job satisfaction and continued commitment (\%248).

- another result that was achieved in this study shows that there is a positive and meaningful relationship between perceived organizational support with organizational commitment also emotional commitment. Based on social transmission theory on the relationship between perceived organizational support and emotional commitment, in social relationship when an individual does a favor to another one, that person sees it necessary to recompense that one's favor; in other word when the staff understand that the organization pays attention to their benefits and see their works valuable and takes care of their health, they feel more attachment to the organization and willingly like to stay there. This result has been similar to Borhani's research result (2002),Taleghani's, Divandazi's, Shirmohammadi's (2005) and Branto (2002).

-The other result of this research shows that there is no meaningful relationship between perceived organizational support with normative commitment and continued commitment; in other words when the staff feel that the organization doesn't pay attention to their benefit , doesn't appreciate their works and their health isn't important for the organization, they don't take positive attitude to the organization and their loyalty decreases, and if they find a better occupational 
opportunity, they simply leave the organization. In this situation, staying in organization is mandatory than optional. It means that the staff continue their working only for the advantages they receive from organization, or because leaving there, their life will face problems. In this situation, their loyalty to the organization is not so much.

The other result of this study indicates that there is positive and meaningful relationship between perceived organizational support and job satisfaction; in other words, the staff's belief of the amount of organization' $s$ attentions to their health, welfare and appreciation of their activities and cooperation causes job satisfaction increase and their positive attitude to their job ; it is confirmed with the result of Rhoades and Eisenberger's study (2002) which demonstrates an increase in organizational support causes individuals' increased attachment to the organization and their job satisfaction.

Other result of this study is the relationship between job satisfaction and organizational commitment has been stronger than the relationship between perceived occupational support and organizational commitment. Therefore, job satisfaction increases occupational commitment more than how perceived occupational support does.

The other result of this study is that the mean of staff job satisfaction (3.27), and organizational commitment (3.32), especially emotional commitment (3.55) is more than the average and the mean of staff's perceived organizational support (2.92) is less than average. This issue indicates that the amount of organizational support from the staff is not much, but the staff are dependent on the organization emotionally and are attached to it.

-Comparing demographic information with the study variables shows:

Gender has relationship only with emotional commitment and the amount of men's emotional commitment is more than women's emotional commitment. Of course the recent result may have been achieved because the number of women is less than men in the statistical sampling.

-The staff with more job experiences enjoy more job satisfaction and organizational commitment. May be one of the result reasons is that they think they can't find another job easily.

-There is no relationship between Education level with job satisfaction, perceived organizational support and organizational commitment.

The study results are confirmative on other findings of researchers who believe the organizations which want to fortify and relate the staff and organization should pay attention to the increasing factors of organizational support and job satisfaction. Researches emphasize that organizations which want their staff to be related to them emotionally, they should prove their commitment by supplying a supporting environment. For this purpose, the organization can supply staff a suitable condition for occupational improvement and job promotion; organization should also give the staff more freedom and free will and it should obey the rules in rewards distribution.

\section{Conclusions}

A. As it is understood from the research that the staff perception from organization support isn't so strong and is less than the average level; it needs more organization managers' attention. In other words, despite staff's commitment to the organization, the organization doesn't pay attention to them appropriately; therefore it should be mentioned that for increasing the staff perceived organizational support, they should provide welfare facilities (sport, entertainment, etc.); they should send them messages in different occasions and should pay more attention to their families.

B. According to this achieved point which indicates increased job satisfaction causes an increase in organizational commitment. Thus, managers should pay fair and suitable awards, provide occupational promotion opportunities and improve relationship (cooperation and empathy) among staff via planning.

C. According to this research result which indicates the staff with more experiences enjoy more job satisfaction and organizational commitment. Managers should introduce more experienced staff for high responsibility occupations.

D. In order to increase staff organizational commitment, it's suggested that the managers should use precautionary methods such as continuous poll from staff periodically to determine staff perceived organizational support, and they should consider their suggestions and change them to executive solutions.

\subsection{Suggestions for Further Research}

According to perceived organizational support and the way of its formation can be effective on the staff's attitude and behavior in organization, some further research suggestions are presented, here:

A. The consequences and effective factors on the staff perceived organizational support can be studied.

B. The relationship between perceived organizational support and other organizational variables such as 
organizational justice, organizational trust and organizational identity can be studied.

C. Analysis of the relationship between staff job satisfaction with the organizational effectiveness or efficiency.

\section{References}

Abtahi, Seyed Hasan, Molaee, Naser (2005). The Relationship Between Skillful Commitment and Organizational, Tadbir Magazine, No. 177.

Amirkabiri, Alireza (2009). Strategic Management, Tehran: Negah Danesh Publishing.

Aarabi, Seyed Mohammad, (2011). Management essays Collection, Tehran: Cultural Researches Office.

Bagheri, Moslem, Tavalaee, Rouhollah (2010). The Effect of Organizational Commitment Survey on Organizations Function, Police Human Development, 7(30):73-96.

Beranvand, Ali (2004). A Survey of Amount of Education Teachers' Occupational Commitment in Cheghlondi District, A Thesis of Lorestan Governmental management center. Lorestan University, Khoramabad, Iran.

Pourebrahim, Sohrab (2004). A Survey between Organizational Culture and The Function of Mellat Bank Branches in Tehran, Master of Art Thesis, Management Collage, Tehran, University, Tehran, Iran.

Javaherizade, Naser (2007). Guide of Personal Supply and Compilation, Tehran: Farhange Zaban Publishication.

Hafeznia, Mohammadreza, (2006). An Introduction to Research in Human Sciences, $12^{\text {th }}$ Edition, Tehran : Samt Publishing.

Darvish, Hossein (2007). A Survey of Effective Factors on Staff Job Satisfaction, Management Culture Magazine, The $5^{\text {th }}$ Year, No.16.

Dessler, Gary (1999). Human Resource Management Theory, (Ali Parsaeian and Seyed Mohammad Aarabi, Trans.) Tehran: Cultural Researches Office.

Daft, Richard L. (1998). Organization Designing and Theory (Ali Parsaeian and Seyed Mohammad Aarabi, Trans.) Tehran: Cultural Researches Office.

Delavar, Ali, (2001). Research in Psychology and Training Sciences, Tehran: Virayesh Publication.

De Vaus, D. A. (2007). The Survey in Social Researches, Tehran: Ney Publication.

Dubrin, Andrew J. (2008). Applicable Psychology, (Gholamreza Memarzade, Tehran, Hojat Taheri Gudarzi , Alborz Gheytani, Trans.) Tehran: Basarang Publication.

Robbins, Stephen P. (1995). Organizational Behavior Management, (Ali Parsaeian, Seyed Mohammad Aarabi,Trans.) Tehran: Commercial Researches and Studies Institute.

Rezaeian, Ali, (1995). Organizational Behavior Management, Tehran: Management Faculty Publication, Tehran University.

Rezaeian, Ali (2001). Organizational Behavior Management, Tehran: Tehran University Publication.

Rokninejad, Mehrdad (2010). New Models and Theories of Organizational Commitment 1-5, Tehran.

Zaki, Mohammad Ali (2006). A Survey and Assessment on Organizational Support, The Economical and Official Science Faculty Magazine, Isfahan University Publication, Iran , No.3.

Zaki, Mohammad Ali (2006). A Survey about the Role of Social Exchange in Sociology Theory in Organizations, Proceedings of $4^{\text {th }}$ International Management Conference Journal, Tehran, pp.2-4.

Sekaran, Uma, (2009). Research Styles in Management, (Mohammad Saebi and Mohammad Khoramabadi, Trans.) Tehran: Planning and Management Education and Research Institute, Tehran.

Seyedjavadin, Seyed Reza (2009). Human Resources Management, Tehran: Terme Publication.

Shakerinia, Iraj, Nabavi,Seyed Sadegh (2010). Relationship Between Job Satisfaction and Perceived Organizational Support with Organizational Commitment, Management Studies Quarterly , No.5, pp.2-5.

Shafiabadi, Abdollah (1996). Skilful and Occupational Consultation and Guide, Tehran: Roshd Publication.

Taleghani, Gholamreza, Divandazi, Ali, Shirmohammadi, Melika (2009). Perceived Organizational Support Effects on the Staff Commitment and Organizational Function, Iran Management Science Quarterly, 4th year, No.16, pp1-4.

Talebpour, Mehdi (2001). The Analysis of Managers Clerks and Scientific Members' Occupational Attitude in Iran Physical Education Faculty and Its Relationship with Organizational Atmosphere (PH.D Thesis), Tehran University.

Madani, Hossein, Zahedi, Mohammad Javad (2005). Precedence Determination of Effective Factors on Staff Organizational Commitment, Iran Sociology Magazine , 6 (1), pp.3-33.

Madani, Hossein (2005). A Survey of Amount of Organizational and Effective Factors on It (Special Study on Iran Industrial Company, Human Resources Institute), 2nd Conference Articles Collection of Human Resources Extension and Iran Industrial Reconstruction, Tehran: Bargozide Publication Office.

Momeni, Mansoor (2008). Statistical Analysis by the Use of SPSS, Tehran: Ketabe no Publication.

Mirsepasi, Naser (1998). Human Resource Management and Work Relationship, Tehran: Mir Publication.

Mirsepasi, Naser (2009). Human Resource Strategic Management and Work Relationship , Tehran: Mir Publication.

Mirderikvandi Rahim (2010). Job Satisfaction and Its Evaluating Style, Management Quarterly,Tehran, No. 38, pp.1-7.

Robert, Faslo Peter, and Davis - Lamastro Valerie (1990). Perceived Organizational Support and Employee Diligence, Commitment and innovation, Journal of Applied psychology ,75(1),pp.50-51.

Ayers, Jennifer parker (2010). Job Satisfaction, Job Involvement, and Perceived Organizational Support as Predictors of Organizational Commitment, Washington: Walden University Publication.

Brown, B Barbara (2003). Employees Organizational Commitment and their Perception of Supervisors Relation - Oriented and Task Oriented Leadership Behaviors, Virginia Polytechnic Institute and State University. 
Bull, Frederick, Howard, Ian (2005). The Relationship between Job Satisfaction and Organizational Commitment amongst High School Teachers in Disadvantaged Areas in the Western cape, Cape Town: University of the Western Cape.

Uyger, Akyay (2009). A Study in to Organizational Commitment and Job Involvement, An Application towards the Personnel in the Central Organization for Ministry of Health in Turkey, Ozean Journal of Applied Sciences 2 (1)

Lok, Peter, Wang, Paul z, Westwood,Bob (2007). Antecedents of Job Satisfaction and Organizational Commitment and the Mediating Role of Organizational Subculture, Adelaide :University of South Australia.

Beenet,.H. \& Durkin,.M. (2000). The Effects of Organizational Change on Employee Psychological Attachment as Exploratory Study, Journal of Managerial Psychology, 15(2):120-146. 